DOI: https://doi.org/10.18371/fp.2(34).2019.178401

JEL Classification Q18

\title{
RATIONAL USE OF RESOURCES AND INTRODUCTION OF INNOVATIVE TECHNOLOGIES IN THE DEVELOPMENT OF AGRICULTURE IN KAZAKHSTAN
}

\author{
GRIDNEVA Yelena Evgenevna \\ Candidate of Economic Sciences, \\ professor «Kainar» Academy \\ Republic of Kazakhstan, Almaty \\ ORCID ID: http://orcid.org/0000-0002-3279-2036 \\ e-mail:elengred@mail.ru
}

\author{
KALIAKPAROVA Gulnar Shaimardanovna \\ PhD, Associate Professor «Kainar» Academy \\ Republic of Kazakhstan, Almaty \\ ORCID ID: http://orcid.org/0000-0002-1859-9774 \\ e-mail:GK_2003@rambler.ru
}

\author{
ALPYSBAYEV Kaisar Serikuly \\ Senior Lecturer «Kainar» Academy \\ Republic of Kazakhstan, Almaty \\ ORCID ID: http://orcid.org/0000-0003-3349-701X \\ e-mail:kaisaralp@gmail.com
}

\begin{abstract}
Rational use of resources and introduction of innovative technologies in the context of globalization become determining factors for the growth and development of Kazakhstan's economy and forming balanced, proportional to the degree of develo-pment increase of all sectors of the economic complex, including agriculture and livelihoods of society as a whole. The essence and substantiation of the significance of the indicator "rational use of resources" are given. The article deals with the differences in the rational use of resources, taking into account industry specifics, the type of resources and the final effects of their use. Foreign practice of the introduction of new technologies, automation and digitalization is characterized. The authors reveal the potential opportunities for introducing innovations and their impact on the development of agriculture in Kazakhstan.
\end{abstract}

Keywords: Kazakhstan, agriculture, rational use of resources, scientific and technological progress, innovation, investment.
Аннотация. Рачиональное использование ресурсов и внедрение инновачионных технологий в условиях глобализаиии становятся определяюшими факторами для роста и развития казахстанской экономики, формирования сбалансированного и пропориионального по степени развития повышения всех отраслей хозяйственного комплекса, в том числе сельского хозяйства, и жизнеобеспечения общества в иелом. В статье раскрыта сущность и дается обосновании значимости показателя "рациональное использование ресурсов»; выявлены различия в рачиональном использовании ресурсов с учетом отраслевых особенностей, вида ресурсов и эффектов их использования; охарактеризовано зарубежную практику внедрение новых технологий, средств автоматизаиии и иифровизачии; выявлено потенциальные возможности внедрения инноваџий и их влияние на развитие сельского хозяйства Казахстана.

Ключевые слова: Казахстан, сельское хозяйство, рациональное использование ресурсов, нау- 
Introduction. In modern conditions, the main problem of the development of human development is the rational use of available natural resources, the need for which is caused by an increase in their consumption due to the increasing influence of demographic factors, in particular population growth and life expectancy, against the background of a general reduction in vital natural resources, in particular reserves water, food, raw materials. It is possible to ensure the rational use of natural resources only through streamlining the structure of production and consumption based on modern scientific and technological achievements and environmentally friendly entrepreneurship. They will contribute to sustainable economic development, reduce inefficient use of natural resources and the amount of harmful emissions, and ensure a stable ecological balance. To solve these problems the Concept of Sustainable Development was adopted by the world community in the 21 st Century. The highways of implementation of it are determined by the Sustainable Development Goals (SDGs). In this regard, like many countries of the world, Kazakhstan supported the SDGs, identifying priorities and tasks in the Strategy "Kazakhstan - 2050". The Strategy deals with the development of agriculture and rural areas, attracting investments, introducing innovations, increasing productivity and the competitiveness of agricultural products under the mandatory condition of rational use of natural resources.

Literature Review and Problem Statement. The rational use of resources in agriculture is devoted to many re- search topics. Research in this area is carried out by such Kazakhstani scientists as: A.Yu. Asetova, Z.D. Dyusenbekov, R.G. Mirsantov, G.Zh. Seytkhamzina, T.I. Scheglova and others. Problematic aspects of the introduction of innovative technologies, ensuring the effective development of agricultural production are considered in scientific works of R.T. Dulambaeva, A. Kurishbaev, A.S. Narynbaeva, L.A. Omarbakiyev, A. Sagitov, Zh.S. Temerbulatova and others. However, the practical importance of the rational use of resources and the need to accelerate the innovative development of agriculture in Kazakhstan determine the relevance of further research.

The purpose of the research is to determine the essence and substantiation of the significance of the indicator "rational use of resources", the differences in the rational use of resources, taking into account industry characteristics, as well as the type of resources and the final effects of their use; to study the foreign practice of the new technologies, automation and digitalization introduction; to assess the potential for introducing innovations and their impact on the development of agriculture in Kazakhstan.

Results of the Research. Kazakhstan occupies the ninth place in the world in terms of area, has a good geographical position, being both in Central Asia and in Eastern Europe. This determines its natural landscape and climatic features, affects the structure of production of the main types of agricultural products. So, in the south of the country viticulture, horticulture, melon cultivation, as well as 
the production of the main grain crops spring wheat, barley, oats, etc., are widely developed due to the heat, sugar beets, rice, cotton plantation. The north of $\mathrm{Ka}-$ zakhstan is a land of livestock and poultry, growing crops and cotton. The western part of the country has large areas of meadows and pastures, which, of course, has become decisive factor for the development of animal husbandry. About $70 \%$ of arable land is sown with wheat, and the rest - with barley, millet and rye. The east of Kazakhstan is famous for sunflowers growing, as well as welldeveloped meat and dairy farming. The total agricultural area is 222.6 million hectares, most of which are occupied (about $85 \%$ or 189 million hectares); $12.8 \%$ (24 million hectares) are under arable land and $2.2 \%$ - under the land.

It is mentioned that agriculture is one of the key industries for the economic development of the Republic of Kazakhstan, which ensures its recognition on the world market as the largest exporter of flour, wheat and cotton and other types of agricultural products [1].

However, the experience of countries of the world with different economic potentials, climatic conditions and natural resources shows that it's impossible to achieve high results in increasing agricultural productivity only by expanding the area of fields and increasing the volume of fertilizers applied. Such approach gives a short-term effect of increased growth and increased yields, with effects directly to profitability and profit drop, environment damage and natural resources depletion.

In this regard, modern innovative technologies, digitalization and automation of all its processes open up new op- portunities for agricultural development. These processes will allow modern Kazakhstan to preserve natural resources and, at the same time, strengthen its competitive position.

Considering the introduction of new technologies, automation and digitalization from the perspective of an innovative project, it's necessary to observe the principle of the rational use of resources - "the maximum possible effective use of modern equipment and technology in order to preserve and protect existing national natural resources in the production of natural and high-quality agricultural products". Then, to determine the effectiveness of an innovative project, it is advisable to use the indicator "rational resources use " (RRU), taking into account the characteristics of various groups of agricultural producers. The essence of the rational use of natural resources and its basic principles are disclosed in the international document "The concept of sustainable economic development."

It should be noted that different indicators of the resources use are used to determine the effectiveness of an innovative project in different sectors of the economy. The RRU indicator should take into account such resources as water, land, labor resources, etc., which can be used in subsequent periods in the future. It should be scientifically based and take into account industry characteristics, the value of resources used and product diversification. The introduction of the RRU indicator in innovative practice requires legislative support at the state level, which, in our opinion, will contribute to the formation of a new attitude to the use of natural resources. 
It is important to determine the differences in the rational use of resources, taking into account industry specifics, the type of resources and the final effects of their use.

For example, the first industry group creates a product based on the direct use of resources (mining, energy, construction materials, metallurgy and agriculture). The rational use of resources should include the most complete extraction of mineral resources, the conservation of land around the mining facility, the reduction of land costs for transportation and the multilateral production of the final product, that is, the full use of the natural content of this product. Wherein, it is important to save more land, that can be used for other purposes. At the place of oil deposits, the land, as a rule, is not fertile, but it is also a resource. As a result of science development, in the future it is quite likely that there will be an opportunity to rationally use these lands. Science is developing, it is quite likely that in the future these lands will be also used rationally. For example, American scientists received 3 million US dollars for the design of a processing plant for the production of rubber from milky juice of dandelion roots, which does not require fertile land and large areas [2, p.3]. A similar experience, with a favorable outcome, can be used in our country to rubber production. So, land conservation can help to increase the production resource in the future.

The main direction of improving production in agriculture (crop production) is to reduce the cost of production (by cost optimization - fuel, fertilizers, electricity, seeds, etc.) and increase profits from products sales. At the same time, highly efficient resource-saving technologies are gaining importance, which on the one hand are financially beneficial for agricultural producers (economic effect), and on the other hand, they reduce the environmental burden on the environment on a national scale (ecological effect).

The second industry group (engineering, electronics) is less directly related to the use of resources. Its determining factor is labor productivity increase, and, on this basis, the rational use of resources.

The main factor for the third industry group (chemical industry, household goods, textile industry) is resource saving that is influenced by know-how and the replacement of natural raw materials with artificial ones [3, p. 26].

There is other situation with the fourth group (food and clothing industries), that creates products for personal consumption of the population. Rational use of resources means obtaining a product that promotes health and human development, which is also a part of economic resources [4, p. 15].

The most important priorities for the development of agriculture are: rational use of land, improving soil quality, increasing fertility, developing livestock and crop production, improving the welfare of the population of rural areas. The Government of the Republic of Kazakhstan approved the "Rules for the rational use of agricultural land" in March, 2015. These rules note that obtaining a crop yield of less than $85 \%$ of the average district indicator for the corresponding crop for 3 consecutive years is an irrational use of agricultural land [5]. 
In Kazakhstan, a new program for the development of the agro-industrial complex is being implemented [6]. This program is aimed at supporting the state of priority crops: the process of reducing wheat crops in favor of niche crops (legumes and oilseeds), that is, organic and environmentally friendly products, as well as grown without genetically modified technologies use. Often, such crops provide a high level of profitability and do not require significant investments in the production organization.

This indicates that the predominant part of the territory of Kazakhstan requires a more rational and active use of the adaptive system of agriculture. Therefore, ensuring the accelerated transfer of agriculture to the latest industrial and innovative technologies, which began to be used in the republic in recent years, is official becoming the main direction of the state agro-technological policy.

In modern conditions, in addition to replacing modern and economical equipment and technology, it is possible to achieve effective resource conservation using information technology. According to this, technical innovations and organizational methods that allow the company to precisely regulate and monitor the use of all resources, are applied.

Over the past century, a huge number of scientific discoveries and brilliant innovative products have been carried out in the world. It helps to increase the yield and improve the genetics of crops.

Some examples of the introduction of innovations in foreign countries that determine the progress of agricultural development, will be considered.

In Dominican Republic, in order to exterminate the Mediterranean fruit fly (a dangerous pest of fruit crops), a technique for using sterile insects (TSI) has been developed, which does not require the use of chemicals and is an environmentally friendly method to preserve and control the natural environment of insects.

In Tanzania, the local species of Allanblackia trees are used. The seeds of this tree are rich in nutrients, that is why they are used in creams, skin lotions, margarine and soap production. The products are in demand all over the world and, therefore, are a reliable source of income for the country's population.

In Africa, and Asia, mobile application "Locust 3" is used. It's information, communication and satellite technology, integrated into a single monitoring system and operational detection of desert locusts.

In Zambia, the artificial intelligence system "Agripredict" is popular. Using an ordinary photo from a mobile phone, "Agripredict" allows to identify pests and predict the likelihood of their invasion, the occurrence and development of plant diseases, as well as to predict adverse weather conditions, such as drought, floods or a cold atmospheric front [6].

In Russia, the integrated cloud service created on the Geo Look platform "ANT" is used. It is a precision farming technology for monitoring all production processes from anywhere in the world and the effective management of agricultural production. Using satellite imagery continuously, this system monitors the process of crop development, monitoring changes, monitoring the state of the field and crop growth by vegetation indices, comparing the data with plant growth in this climatic zone [7]. 
In Mexico and Russia, "Solid water" is used, that is polymer granules from natural monomers, that absorb water and retain moisture in the soil $(1 \mathrm{~kg}$ absorbs 500 liters of water). The granules can be used from 5 to 10 years, since they do not wash out from the soil [8].

Israel is characterized by using technologies for reducing water use and increasing yields. For example, digital technology "Sensilize" helps to use the soil of the earth as efficiently as possible, namely taking into account factors that affect plants, such as soil quality, rainfall, climate, availability of equipment and other possible resources. This increases the adaptability of crops, reduces costs and increases yields. This technology can be used both for growing in greenhouses and in open ground.

The technology of ROOTS Sustainable Agricultural Technologies provides the possibility of taking into account the quality of soils, that with minimal water consumption allows to increase yields. It is in demand in Australia, Israel, the USA, Chile, Georgia, Sri Lanka and China [9].

Nowadays, we can observe a trend of the transition from farming on open ground to closed (in greenhouses) using energy-saving technologies with fully automated and computer control [10]. Innovative and technological know-how are also actively introducing in Kazakhstan. A unique 35-meter underground greenhouse was built in the eastern part of the country. Despite the difficult climatic conditions in the region and long winters, tropical fruits such as lemons, oranges, bananas, pineapples, muraya, ficus, cacti, etc., are growing underground at a depth of almost three meters.
There are more than 80 greenhouses with an area of 10 hectares in the Almaty region. Tomatoes are grown on 7 hectares; other 3 hectares are planted with cucumbers. In the season more than 6.5 thousand tons of products are collected. The technologies used here are based on the experience of leading European countries [11].

The introduction of innovations in the development of agriculture in Kazakhstan requires significant financial resources. Unfortunately, farmers do not have sufficient volumes of their own investments, and attracting external investors is complicated by an insufficient amount of working capital, low level of financial stability, business activity and competitiveness. Therefore, long-term investment in agriculture has become largely dependent on state funding. Investments are directed to updating the material and technical base, introducing multi-operational agricultural machinery and equipment, resource-saving technologies, differentiating agricultural technologies in accordance with the specifics of agricultural zones and territories, and using biotechnologies to protect plants and soil.

Conclusions. The introduction of the indicator of rational use of resources will allow, to a certain extent, to resolve the existing contradiction between constantly growing needs and limited resources, to preserve natural resources for a longer time and to ensure maximum efficiency of their use. This indicator should be included in the system of estimated indicators of the effectiveness of innovative projects in agriculture. This will allow the agricultural sector of Kazakhstan to receive the following advantages: 1) the 
ability to preserve available resources for future generations; 2) the preservation of the natural product and improving the quality of products for consumption; 3 ) the creation of a promising niche for environmentally friendly and high-quality agricultural products (rational use involves the preservation of a natural product without GMOs for the consumption); 4) rational use of available resources, meeting the growing needs of society; 5) access to the world markets and increasing the competitiveness of the economy of Kazakhstan.

Innovative processes in agriculture and the rational use of resources should get the necessary state support, which will contribute to technical, technological, economic, organizational renewal and increase the efficiency and competitiveness of the industry. In this case, the main efforts should be directed to: further integration of universities, research institutes and production; new equipment and technology selection (technology transfer); investments stimulation in the development of innovations that increases crop yields and soil fertility, provides development and diversity of biological resources; supporting and stimulating investments in the development of energy and resource-saving equipment, as well as high technology in agriculture; support of the development of clusters, technology parks and business incubators; compulsory insurance of innovative technologies in agriculture; development of education, retraining of personnel in agriculture, the development of information and advisory system for agricultural producers; database of innovations creation and development.

\section{References}

1. Sel'skoe hozyajstvo v Kazahstane [Agriculture in Kazakhstan]. kazportal.kz. Retrieved from https://www.kazportal.kz/selskoe-hozyaystvo-v-kazahstane [in Russian]. 2. Gol'ceva, L. (2008). Galoshi iz oduvanchikov [Galoshes of dandelions]. Vremya Time, 8(36) [in Russian].

3. Gridneva, Ye.E. (2008). Stimulirovanie innovacionnoj aktivnosti i obespechenie konkurentosposobnosti ekonomiki Kazahstana [Stimulating innovative activity and ensuring the competitiveness of the economy of Kazakhstan]. Al-Farabi Kazakh National University [in Russian].

4. Gridneva Ye.E. (2009). Racional'noe ispol'zovanie resursov kak faktor povysheniya konkurentosposobnosti ekonomiki Kazahstana [Rational use of resources as a factor in increasing the competitiveness of the economy of Kazakhstan]. Al' Pari, 2 [in Russian].

5. Rules for the rational use of agricultural land. (2015, March 27). Order of the Acting Minister of the National Economy of the Republic of Kazakhstan, 268. Retrieved from http://adilet.zan.kz/rus/docs/V1500011549 [in Russian]. 
6. The state program for the development of the agro-industrial complex of the Republic of Kazakhstan for 2017-2021. egov.kz. Retrieved from https://egov.kz/cms/ru/law/list/U1700000420 [in Russian].

7. Innovacii dlya budushhego prodovol'stviya i sel'skogo hozyajstva [Innovation for the future of food and agriculture]. agroinfo.kz Retrieved from http://agroinfo.kz/innovacii-dlya-budushhego-prodovolstviya-i-selskogo-xozyajstva [in Russian].

8. Informacionnye oblachnye servisy dlya APK [Information cloud services for agribusiness]. agropraktik.ru Retrieved from http://agropraktik.ru/blog/1302.html [in Russian].

9. Podguznik spaset ot zasuhi [The diaper will save you from drought]. agropraktik.ru. Retrieved from http://agropraktik.ru/blog/Irrigation/909.html [in Russian].

10. 9 izrail'skih innovacij v oblasti sel'skogo hozyajstva [9 agricultural innovations in Israel]. stmegi.com. Retrieved from https://stmegi.com/posts/36747/9-izrailskikhinnovatsiy-v-oblasti-selskogo-khozyaystva/ [in Russian].

11. Biznes $\mathrm{v}$ ne teplichnyh usloviyah [Non-greenhouse business]. www.zakon.kz. Retrieved from https://www.zakon.kz/4612102-biznes-v-ne-teplichnykhuslovijakh.html [in Russian]. 